\title{
AIDS EM ODONTOLOGIA - ASPECTOS ÉTICOS NAS RELAÇÕES ENTRE PROFISSIONAIS E PACIENTES
}

Joslei Carlos BOHN, Rodrigo RAZZOTO, Antonio Adilson Soares de LIMA

A infecção pelo HIV provoca a AIDS e esta doença gera um estigma em relação aos cuidados destes pacientes por grande parte dos profissionais da saúde. O objetivo desta pesquisa foi investigar a percepção de cirurgiões dentistas e pacientes quanto à conduta de ambas as partes no tocante à infecção pelo HIV. Foram entrevistados 179 indivíduos por meio de questionários individuais, divididos em dois grupos: "pacientes" e "profissionais". Do total de profissionais, 92\% não informariam seu paciente caso fossem HIV+, 76\% nunca realizaram exames para detecção do vírus e $65 \%$ deles já atenderam portadores do HIV. Com relação aos pacientes, $82 \%$ não informariam seus dentistas se portassem o vírus e 55\% nunca se submeteram a exames para detecção do HIV; quando perguntado se continuariam sendo atendidos por um profissional $\mathrm{HIV}_{+}, 58 \%$ dos pacientes informaram que não o fariam. Comparando os dois grupos, $26 \%$ dos cirurgiões dentistas acham que o profissional HIV+ deveria somente trabalhar com pesquisas ou abandonar a profissão, contra $55 \%$ dos pacientes. A pesquisa evidenciou que ainda há preconceito e desconhecimento sobre o risco de infecção por parte dos profissionais e pacientes, e que a portabilidade viral pode influenciar a busca ou a recusa pelos serviços odontológicos.

Palavras-chave: Síndrome de Imunodeficiência Adquirida; HIV; Relações Dentista-Paciente. 